\title{
Rubella and congenital rubella syndrome: global update
}

\author{
Susan E. Robertson, ${ }^{1}$ David A. Featherstone, ${ }^{1}$ Marta Gacic-Dobo, ${ }^{1}$ \\ and Bradley S. Hersh ${ }^{1}$
}

ABSTRACT Worldwide, it is estimated that there are more than 100000 infants born with congenital rubella syndrome (CRS) each year. In 1998, standard case definitions for surveillance of CRS and rubella were developed by the World Health Organization (WHO). In 2001, 123 countries/territories reported a total of 836356 rubella cases. In the future more countries are expected to report on rubella as a global measles/rubella laboratory network is further developed under the coordination of the WHO. Operational research is being conducted to improve rubella surveillance. This includes projects on initiating CRS surveillance, comparative studies on diagnostic laboratory methods, and molecular epidemiology research to expand the global understanding of patterns of rubella virus circulation. In 1996 a WHO survey found that 78 of 214 reporting countries/territories (36\%) were using rubella vaccine in their routine immunization services. By the end of 2002 a total of 124 of the 214 counties/territories $(58 \%)$ were using rubella vaccine. Rubella vaccine use varies by stage of economic development: $100 \%$ for industrialized countries, $71 \%$ for countries with economies in transition, and $48 \%$ for developing countries. A safe and effective rubella vaccine is available, and there are proven vaccination strategies for preventing rubella and CRS. A WHO position paper provides guidance on programmatic aspects of rubella vaccine introduction. The introduction of rubella vaccine is cost-effective and cost-beneficial but requires ongoing strengthening of routine immunization services and surveillance systems.

Key words Rubella, congenital rubella syndrome, surveillance, immunization programs.

Rubella is a mild illness that presents with fever and rash. However, the public health importance of rubella relates to the teratogenic effects when rubella infection is acquired in the early months of pregnancy. Rubella infection of the fetus can result in fetal death or in the birth of an infant with

\footnotetext{
World Health Organization, Department of Vaccines and Biologicals, Geneva, Switzerland. Send correspondence to: Susan E. Robertson, Department of Vaccines and Biologicals, World Health Organization, Avenue Appia, 1211 Geneva 27 Switzerland; e-mail: robertsons@who.int
}

serious congenital birth defects. The congenital rubella syndrome (CRS) is an important cause of blindness, deafness, congenital heart disease, and mental retardation. The worldwide pandemic of rubella in 1962-1965 highlighted the importance of CRS. In the United States of America alone during 1964 and 1965 there were an estimated 11000 fetal deaths and 20000 infants born with CRS (1). This pandemic stimulated the development of rubella vaccines, with the first products licensed in 1969. Uptake of rubella vac- cine in industrialized countries was high; however, rubella vaccine was not included in 1974 in the group of core antigens recommended for children in developing countries by the World Health Organization (WHO) Expanded Programme on Immunization (2). Thus, while rubella and CRS decreased markedly in the industrialized countries, endemic rubella and CRS continued to occur in much of the developing world. This situation received limited attention as a global public health issue until the mid-1990s. 


\section{BURDEN OF CONGENITAL RUBELLA SYNDROME IN DEVELOPING COUNTRIES}

A WHO review carried out in 1996 revealed that 50 developing countries had already conducted substantial studies to assess their CRS disease burden, and more studies have been reported since then (3). As shown in Table 1, special surveillance investigations in developing countries in Africa, the Americas, Asia, Eastern Europe, and the Eastern Mediterranean have documented incidence rates of CRS ranging from 0.4 to 4.3 per 1000 live births (4-17). These incidence rates are comparable to and in some cases higher than those seen in industrialized countries in the prevaccine era (18). Rubella immunoglobulin G (IgG) serosurveys among women of childbearing age indicate the potential risk for rubella infection in pregnant women. Serosurveys from 45 developing countries have shown a wide range of susceptibility: the proportion of rubella seronegative women was $25 \%$ or higher in 12 countries, $10 \%-24 \%$ in 20 countries, and below $10 \%$ in 13 countries (3). These studies document that many women of childbearing age living in developing countries remain at risk for having a child with CRS.

Worldwide, it is estimated that more than 100000 infants are born with CRS each year. Cutts and Vynnycky estimate that in 1996 there were 110000 infants (95\% confidence interval, 14428 to 308 438) affected by CRS in developing countries (excluding the WHO European Region) that had not introduced rubella vaccine (19). A separate estimate for the WHO European Region suggests some 4000 CRS cases occur annually in countries of that Region that have not introduced rubella vaccine (20). A recent global review of CRS sequelae analyzed data from prospective studies with laboratoryconfirmed cases (21). Among infants with CRS, 60\% had hearing impairment, $45 \%$ congenital heart disease, $27 \%$ microcephaly, $25 \%$ cataract(s), $23 \%$ low birth weight ( $<2500$ grams), $17 \%$ purpura, $19 \%$ hepatosplenomegaly, $13 \%$ mental retardation, and $10 \%$ meningoencephalitis.

\section{CONGENITAL RUBELLA SYNDROME SURVEILLANCE}

In 1998 the WHO Department of Vaccines and Biologicals, in collaboration with WHO regional offices and with specialists from the WHO Programme for the Prevention of Blindness and Deafness, developed standard case definitions for CRS surveillance, including for: (1) a suspected CRS case, (2) a clinically con- firmed CRS case, and (3) a laboratoryconfirmed CRS case. These case definitions have been promoted in publications on rubella (22) and in general surveillance standards for communicable diseases $(23,24)$.

A suspected CRS case is any infant less than one year of age in whom a health worker suspects CRS. A health worker should suspect CRS when an infant aged 0-11 months presents with heart disease and/or suspicion of deafness and/or one or more of the following eye signs: white pupil (cataract), diminished vision, pendular movement of the eyes (nystagmus), squint, smaller eye ball (microphthalmos), or larger eye ball (congenital glaucoma). A health worker should also suspect CRS when an infant's mother has a history of suspected or confirmed rubella during pregnancy, even when the infant shows no signs of CRS.

A clinically confirmed CRS case is an infant in whom a qualified physician either detects two or more of the complications from list " $a$ " below or detects one from list "a" and one from list "b." List "a" is: cataract(s), congenital glaucoma, congenital heart disease, loss of hearing, or pigmentary retinopathy. List "b" is: purpura, splenomegaly, microcephaly, mental retardation, meningoencephalitis, radiolucent bone disease, or jaundice that begins within 24 hours after birth.

TABLE 1. Incidence of congenital rubella syndrome (CRS) per 1000 live births, according to population-based studies from developing countries

\begin{tabular}{|c|c|c|c|}
\hline Country & Place & CRS incidence and time period & Reference \\
\hline Brazil & City of Rio Branco & $\begin{array}{l}0.6 \text { per } 1000 \text { live births in } 2000-2001 \text { outbreak, } \\
\text { with } 4.3 \text { per } 1000 \text { live births in peak month }\end{array}$ & 4 \\
\hline Ghana & Ashanti Region & 0.8 per 1000 live births in 1996-1997 & 5 \\
\hline Israel & National & 1.7 per 1000 live births in 1972 & 6 \\
\hline Jamaica & Main institutions for handicapped children, nationwide & 0.4 per 1000 live births in 1972-1981 & 7 \\
\hline Jamaica & National & 0.4 per 1000 live births in 1995 outbreak & 8 \\
\hline Malaysia & University Hospital, Kuala Lumpur & 0.5 per 1000 live births in 1993-1998 & 9 \\
\hline Oman & National & 0.5 per 1000 live births in 1988 outbreak & 10 \\
\hline Oman & National & 0.7 per 1000 live births in 1993 outbreak & 11 \\
\hline Panama & Santo Tomás Maternity Hospital, Panama City & 1.6 per 1000 live births in 1965 outbreak & 12 \\
\hline Panama & Caja de Seguro Social \& Hospital del Niño, Panama City & 2.2 per 1000 live births in 1986-1987 & 13 \\
\hline Russian Federation & Perm Region & 3.5 per 1000 live births in 1994-1996 & 14 \\
\hline Singapore & Kandang Kerabau Hospital, Singapore & 0.9 per 1000 live births in 1969-1970 outbreak & 15 \\
\hline Sri Lanka & Survey of 71 pediatricians & 0.9 per 1000 live births in 1994-1995 outbreak & 16 \\
\hline Trinidad and Tobago & Mt. Hope Women's Hospital, Trinidad & 0.6 per 1000 live births in 1982-1983 outbreak & 17 \\
\hline
\end{tabular}


A laboratory-confirmed CRS case is an infant with clinically confirmed CRS who has a positive blood test for rubella-specific immunoglobulin $\mathrm{M}$ (IgM). A single serum specimen $(1 \mathrm{~mL})$ should be obtained as early as possible within the first year of life, ideally before 6 months of age. In some countries, more sophisticated methods for laboratory diagnosis may be available, and the local reference laboratory should be consulted in advance on specimen collection and transport procedures.

It should be noted that some countries have adopted more sensitive CRS case definitions as they have moved toward eliminating CRS altogether (25). For example, in the Region of the Americas the definition for clinically confirmed CRS includes infants with even a single finding compatible with CRS such as congenital cataract, hepatosplenomegaly, patent ductus arteriosus, purpura, or hearing impairment.

WHO recommends that all countries using rubella vaccine in their national immunization program conduct CRS surveillance, with investigation and laboratory testing of each suspected case in areas where this is feasible and where appropriate laboratory support is available (22). Such surveillance may also be appropriate for countries seeking to assess whether to add rubella vaccine to their national immunization programs. Surveillance is restricted to children 0-11 months of age because it is difficult to confirm rubella as the specific cause of congenital defects in older children. Infants with CRS are likely to be seen at specialty facilities that do not normally participate in the routine communicable disease surveillance system, for example, eye hospitals and hospitals specializing in cardiac surgery. For comprehensive CRS surveillance these facilities should be included in CRS detection, investigation, and reporting activities. In the Americas, CRS surveillance includes the Perinatal Information System of the Latin American Center for Perinatology and Human Development and the Latin America Collaborative Study on Congenital Malformations (25). Enhanced CRS surveillance is recommended following rubella outbreaks, especially where cases have been reported in women of childbearing age.

In 2000, WHO and the United Nations Children's Fund (UNICEF) began to request reports on the annual number of CRS cases from all reporting countries/territories. (In an effort to strengthen collaboration and minimize the reporting burden, $\mathrm{WHO}$ and UNICEF jointly collect information from national health authorities through a standard annual form on vaccine-preventable diseases; the content of the joint reporting form was developed through a consensus process among staff representatives from UNICEF, WHO, and selected ministries of health.) CRS reporting has increased gradually, with 51 of 214 countries/territories providing reports on incidence in 1999, 80 in 2000, and 89 in 2001. There were 39 CRS cases reported in 1999, 181 in 2000, and 50 in 2001. These data highlight that CRS surveillance remains grossly incomplete, with fewer than $0.1 \%$ of estimated CRS cases reported. Many countries have not yet included CRS in their communicable disease surveillance systems. Some countries with well-established CRS surveillance have not submitted complete data to the WHO/UNICEF annual reporting scheme. In general, data appear more likely to be reported from countries with stronger CRS surveillance and countries that have conducted enhanced CRS surveillance following large-scale rubella outbreaks.

Countries reporting the greatest numbers of CRS cases during 19992001 were: Costa Rica, 46 cases in 2000 (0.5 CRS cases per 1000 live births); Brazil, 37 cases in 2000 (0.01 cases per 1000 live births); Sri Lanka, 26 cases in 2000 (0.08 cases per 1000 live births); and Romania, 20 cases in 2000 (0.08 cases per 1000 live births). However, national incidence rates of CRS per 1000 live births can mask high incidence rates in specific geographic areas. For example, epidemiological investigations in the city of Rio Branco in northeastern Brazil found an incidence of 0.6 CRS cases per 1000 live births, a figure 60 times the national average (4).

\section{OPERATIONAL RESEARCH TO STRENGTHEN CONGENITAL RUBELLA SYNDROME SURVEILLANCE}

WHO has sponsored several operational research studies aimed at identifying methods to improve CRS surveillance. In 1992 the Ministry of Health of Oman moved from passive to active surveillance to identify CRS cases resulting from a large-scale rubella outbreak, and this system detected 0.7 CRS cases per 1000 live births in 1993 (11). In Peru, retrospective reviews were conducted among students attending schools for the deaf and blind to identify children with probable or confirmed CRS (26). The WHO Collaborating Centre for Prevention of Blindness at Aravind Eye Hospital in Madurai, India has developed community-based screening for eye signs in young children as a means of identifying suspected cases of CRS (27). Three large-scale prospective CRS surveillance demonstration projects are under way, in India, Myanmar, and Peru, and it is anticipated that these will provide important guidance for other countries.

\section{RUBELLA SURVEILLANCE}

Progress in implementing rubella surveillance on a global basis has been closely linked with progress toward implementing case-based measles surveillance and development of a global measles/rubella laboratory network. Coordinated by WHO, this network includes a hierarchy of subnational, national, regional, and global specialized laboratories that use standard methods for confirmation of measles and rubella. The network provides training for staff of network laboratories; supports regular subregional, regional, and global meetings; and conducts regular proficiency testing of participating laboratories. 
Standard rubella case definitions have been adopted by WHO, including for: (1) a suspected rubella case, (2) a clinically confirmed rubella case, and (3) an epidemiologically confirmed rubella case (22-24).

A suspected rubella case is any patient of any age in whom a health worker suspects rubella. A health worker should suspect rubella when a patient presents with fever, maculopapular rash, and one or more of the following: cervical adenopathy, suboccipital adenopathy, postauricular adeopathy, or arthralgia/arthritis.

A laboratory-confirmed rubella case is a suspected case with a positive blood test for rubella-specific IgM. The blood specimen should be obtained within 28 days after the onset of rash.

An epidemiologically confirmed rubella case is a patient who meets the suspected case definition and is epidemiologically linked to a laboratoryconfirmed case.

In 2000, WHO and UNICEF began to request reports on the annual number of cases of rubella from all reporting countries/territories. Reporting has increased gradually, with 98 of 214 countries / territories (46\%) providing annual rubella case reports in 1999, $109(51 \%)$ in 2000, and $123(57 \%)$ in 2001. There were 874713 rubella cases reported in 1999, 671 393 cases in 2000, and 836356 in 2001. In each of these years, the Russian Federation accounted for $67 \%-68 \%$ of all reported rubella cases worldwide. Countries with more than 20000 rubella cases reported in any one year included Belarus, Bulgaria, Kazakhstan, Poland, and Ukraine. Countries with 10000 to 20000 cases in any one year included Argentina, Brazil, Mexico, and Venezuela. The fact that the greatest numbers of cases are reported from Europe and the Americas likely reflects better rubella surveillance in these regions.

\section{GLOBAL MEASLES/RUBELLA LABORATORY NETWORK}

Following approval by the World Health Assembly in 1988 of Resolution
WHA41.28, which dealt with eradicating poliomyelitis, a global polio laboratory network was established by WHO to support international surveillance for polioviruses through laboratory investigation of stool samples from persons with acute flaccid paralysis. That global polio laboratory network now covers all six WHO regions and is comprised of 145 laboratories responsible for a wide range of activities, including poliovirus isolation, intratypic differentiation to distinguish wild and vaccine poliovirus, and genomic sequencing (28). It was envisioned that this network could provide a base for the development of a global measles/ rubella laboratory network (29-30). The resulting measles/rubella laboratory network has built upon the capital investment, infrastructure development, and experience of the polio network by using many of the same laboratories, or at least the same institutions, for measles and rubella testing. A laboratory network with the capacity to confirm both rubella and measles cases is important since both diseases may be detected through fever and rash surveillance, and often the two diseases are clinically indistinguishable. The procedure for case confirmation is the same for measles and rubella, using a disease-specific IgM enzyme-linked immunosorbent assay (ELISA) that is sensitive enough to confirm cases from serum samples collected early in the course of the disease.

There are five main objectives in establishing a global network of laboratories to support various aspects of measles and rubella control. The first objective is to develop standardized methods and quality control for the laboratory confirmation of rubella and measles and to provide the necessary support to conduct these routine procedures. This will ensure that results from any network laboratory should be of known sensitivity and specificity and will be directly comparable with results from any other laboratory in the network. The second objective is to establish reference centers that can resolve problems encountered in the laboratory diagnosis of rubella and measles. The third objective is to provide training for staff of regional and national laboratories. The fourth objective is to provide a source of reference reagents and expertise for the development and quality control of improved diagnostic tests. The fifth objective is to provide a repository for rubella and measles virus isolates for molecular epidemiology investigation. Individual laboratories will not be expected to undertake the full range of tasks listed above but will perform specific duties according to national and regional needs.

The global measles/rubella laboratory network is being organized on four levels: (1) global specialized laboratories, (2) regional reference laboratories, (3) national laboratories, and (4) subnational laboratories. Global specialized laboratories will set the technical standards for laboratory diagnosis; their responsibilities extend to measles and rubella laboratories in all regions and all countries. Regional reference laboratories are "centers of excellence" that will serve as reference laboratories for national laboratories in neighboring countries and as national laboratories in their own countries; each region may have up to three or four regional reference laboratories. National laboratories will test specimens from suspected cases by $\operatorname{IgM}$ ELISA and report directly to the national staff responsible for rubella and measles surveillance and control. The number of national laboratories and the order of their establishment will depend on the epidemiological priorities and the resources available. Subnational laboratories may be established in some countries with large populations or where geographical barriers present transportation difficulties in sending samples to a single national laboratory.

Two global specialized laboratories for measles and rubella have been identified. One is at the United States Centers for Disease Control and Prevention, in Atlanta, Georgia, and the other is at the Health Protection Agency, in London, United Kingdom. These high-level laboratories will be 
involved in genetic sequencing studies, the maintenance of virus strain banks, and other special research projects.

It is essential that the laboratory network be planned in tandem with regional control and elimination programs and that the network be established with properly trained personnel, suitable equipment, and appropriate reagents. All six of the $\mathrm{WHO}$ regions have identified or are in the process of establishing regional reference laboratories for measles and rubella. As of mid-2003, 155 countries had established national measles/rubella laboratories and 222 staff from 98 countries had attended WHO one-week laboratory training courses or received a "one-onone" training visit to their laboratory. In addition, 331 subnational laboratories had been established in China.

A strong quality assurance program is vital for ensuring a robust laboratory network. Regular proficiency testing is already under way, and it will serve as one part of comprehensive laboratory accreditation. Comparative studies of the sensitivity and specificity of various rubella IgM ELISA kits have been carried out (31), and an assessment of commercially available rubella avidity assays is proposed for late 2003 (S. Ratnam, personal communication, 2003).

A global review of data on genetic sequencing of rubella virus by a consortium of four laboratories demonstrated that there are two primary genotypes of rubella virus (32). Genotype I contained viruses from Europe, Japan, and North America, while genotype II contained rubella viruses from China and India. Further molecular epidemiology data are needed to expand the global understanding of patterns of rubella virus circulation, which remain unknown for many countries and some regions. In the past few years there has been renewed interest in sequencing rubella strains, as appropriate specimens are increasingly being collected from patients with rubella and CRS. For example, recent data from Brazil show that two strains of rubella virus were cocirculating during 1996, 1997, and 1999; both strains are classified as genotype
I (33). In Myanmar, rubella virus strains circulating in 2001 were found to belong to genotype I, distinct from the genotype II strains identified in neighboring China. ${ }^{2}$ Rubella is a difficult virus to isolate in culture, and at least one laboratory is working on developing a cell line that is highly sensitive to rubella virus and demonstrates an easily distinguished cytopathic effect (J. Icenogel, personal communication, 2003).

\section{RECOMMENDATIONS ON RUBELLA VACCINE INTRODUCTION}

In 2000 an international conference on preventing CRS was organized by WHO, with partial support from the March of Dimes Birth Defects Foundation and the United States Centers for Disease Control and Prevention (29, 34). This was the first global meeting on rubella since 1984, and it provided an in-depth examination of the disease burden due to CRS, immunization strategies, monitoring vaccine coverage, conducting surveillance, and operational research needs. Following the meeting, the WHO Department of Vaccines and Biologicals published a position paper on rubella vaccines, which provides extensive guidance on programmatic aspects of introducing rubella vaccine (35). A global review of economic studies (cost-benefit or costeffectiveness analyses) on rubella and rubella vaccines identified 22 studies, with 10 of them conducted in developing countries (36). All the cost-benefit analyses had a benefit-cost ratio greater than 1 (range of 1.1 to 38.8), and all the cost-effectiveness studies indicated that rubella immunization was a costeffective means of reducing the impact of CRS. Data from the English-speak-

\footnotetext{
2 Kyaw-Zin-Thant, Minahara H, Kyaw-Moe, SoeThein, Thein-Thein-Myint, Katow S. Genome identification and tracing the molecular epidemiology of Myanmar rubella virus strains in the year 2001 [meeting presentation abstract]. Program and Abstracts, 40th Annual Meeting of the Infectious Diseases Society of America, Chicago, 24-27 October 2002. Alexandria, Virginia, United States: Infectious Diseases Society of America, 2002.
}

ing Caribbean countries and Suriname indicated a benefit-cost ratio of 13.3 for a campaign to eliminate CRS by providing rubella vaccine to all males and females 1-30 years of age. This estimate did not include the costs of routine delivery of measles-mumpsrubella (MMR) vaccine to one-yearolds, which had already been implemented. It was estimated that the cost of rubella elimination in these countries during 1997-2017 would be US\$ 4.5 million, compared with more than US\$ 60 million for treatment of CRS cases in the absence of an elimination initiative. Spurred in part by these data, the Council for Human and Social Development of the Caribbean Community (CARICOM) approved a resolution in April 1998 stating that every effort would be made to eradicate rubella as well as to prevent the occurrence of new cases of CRS in the Community by the end of 2000 (37).

Within WHO, rubella vaccination is under the responsibility of the WHO Department of Vaccines and Biologicals. However, public health aspects of rubella and congenital rubella syndrome have been given attention at meetings and in training materials produced by several other WHO programs, including the Programme for the Prevention of Blindness and Deafness (38), the Department of Child and Adolescent Health and Development (39), and the Department of Reproductive Health and Research (40). Also, several WHO regions have given special emphasis to rubella vaccine introduction.

The WHO Region of the Americas was certified as having interrupted transmission of indigenous wild poliovirus in 1994 (41). Following on this achievement, the Pan American Sanitary Conference in 1994 established the goal of eliminating measles from the Region of the Americas by the year 2000 (42). (The Pan American Sanitary Conference is the supreme governing authority of the Pan American Health Organization (PAHO); PAHO serves as the Regional Office for the Americas of the World Health Organization.) To measure progress towards achieving the measles elimination goal, a Re- 
gional fever and rash surveillance system was established in the Americas. Serum from a suspected measles case was tested initially for measles IgM antibodies, and, if negative, the sample was tested for rubella IgM antibodies. After the acceleration of measles elimination activities during the mid-1990s, the fever and rash surveillance system clearly demonstrated that measles virus circulation had either been interrupted or reduced to extremely low levels throughout the Region (43). However, many cases of fever and rash illness continued to be reported, and a significant proportion of these cases were caused by rubella. For example, in Brazil between 1993 and 1996 nearly $50 \%$ of patients in whom measles was ruled out were diagnosed as having rubella (44). The documentation of rubella virus circulation stimulated pilot projects in several countries to determine the public health burden of rubella and CRS in the Region (45). Once the burden of disease had been confirmed, efforts were made to implement appropriate immunization strategies for rubella and CRS prevention throughout the Region, and these activities were strengthened in 1998 (25, 46). In 1997 the Americas reported more than 126000 rubella cases. In 2002 this number had been reduced by $90 \%$, to fewer than 12000 cases. In September 2003 at the annual meeting of PAHO's Directing Council, ministers of health from all the countries of the Americas set a goal of eradicating rubella and CRS from the Region of the Americas by 2010 (47).

In the WHO European Region, targets for eliminating indigenous measles and rubella were established in 1984. In 1999 a health policy framework for the European Region set a target for reducing the incidence of CRS to less than 1 per 100000 live births by 2010. To give impetus to achieving this target, a Regional plan has been developed for elimination of measles and prevention of congenital rubella infection (20). This has encouraged the commitment of governments and is leading to mobilization of needed resources (48). By 2002 more than $80 \%$ of countries in the European Region used
MMR vaccine, and it is anticipated that all will do so by 2007. Innovative methods for surveillance of measles, rubella, and CRS are being developed. For example, in some countries abortion registers may be a useful means of identifying women who were infected with rubella in early pregnancy.

In the WHO Eastern Mediterranean Region a resolution was adopted in 1997 that called for the elimination of measles in the Region by 2010 (49). In the 23 Member States in the Region, measles elimination has become a priority for 18 polio-free countries. The remaining 5 countries (Afghanistan, Djibouti, Pakistan, Somalia, and Sudan) have focused efforts on acute flaccid paralysis surveillance for polio and on measles control efforts specifically aimed at reducing measles mortality. Since 1995 the Arab Gulf countries (Bahrain, Kuwait, Oman, Qatar, Saudi Arabia, and United Arab Emirates) have also given special attention to control of rubella (50).

Other WHO regions-Africa, SouthEast Asia, and the Western Pacificare undertaking special efforts to decrease measles mortality. A number of nations have organized mass campaigns using measles-rubella (MR) or MMR vaccine, and other countries are planning such activities. The capabilities of the measles/rubella laboratory network are being developed in these regions, and it is likely that rubella control will receive more attention in coming years.

\section{COUNTRIES USING RUBELLA VACCINE}

There has been a dramatic increase in the use of rubella vaccine over the past 6 years. In 1996 a survey conducted by WHO found that 78 of 214 reporting countries/territories (36\%) were using rubella vaccine in their routine immunization services (50). By the end of 2002 this had increased to $124(58 \%)$ of reporting counties/ territories, and this information was being collected routinely by WHO and UNICEF on an annual basis (Figure 1). By WHO region, the most striking in- creases occurred in the Region of the Americas ( $47 \%$ to $94 \%$ of all countries/territories), the European Region (64\% to $84 \%)$, and the Western Pacific Region ( $31 \%$ to $59 \%$ ) (Figure 2). Rubella vaccine use varies by the economic status of the country. Among the 27 industrialized countries, rubella vaccine use is $100 \%$; for the 28 countries with economies in transition, rubella vaccine use has risen from $36 \%$ in 1996 to $71 \%$ in 2002; and for 159 developing countries/territories, rubella vaccine use has risen from $28 \%$ in 1996 to $48 \%$ in 2002 . Among the 124 countries/territories that use rubella vaccine routinely, 89 of them $(72 \%)$ include two doses. The first rubella vaccine dose is usually scheduled at age 12-15 months, and the second dose is scheduled either prior to school entry or in the early teen years.

\section{DISCUSSION}

By the end of 2002, 90 countries/ territories had not yet introduced rubella vaccine into their national immunization schedules. However, three countries in the Americas-the Dominican Republic, Haiti, and Peruwere planning to introduce rubella vaccine in 2003 or 2004 (25), and it is likely that several countries from other WHO regions will also do so.

WHO recommends that the priority in preventing CRS is to protect women of childbearing age from rubella. If rubella immunization of children is implemented, rubella vaccination of adult women should be introduced at the same time or earlier. Rubella vaccine should be added to the childhood immunization schedule only if coverage greater than $80 \%$ can be sustained on a long-term basis (35). Inadequately implemented childhood vaccination can lead to an increase in susceptibility in women of childbearing age, with the potential of increased numbers of cases of CRS. Consequently, it is essential that childhood rubella vaccination programs achieve and maintain high levels of coverage.

Altogether, 21 countries not yet using rubella vaccine have sustained 
FIGURE 1. Countries/territories with rubella vaccine in the national immunization system in 2002

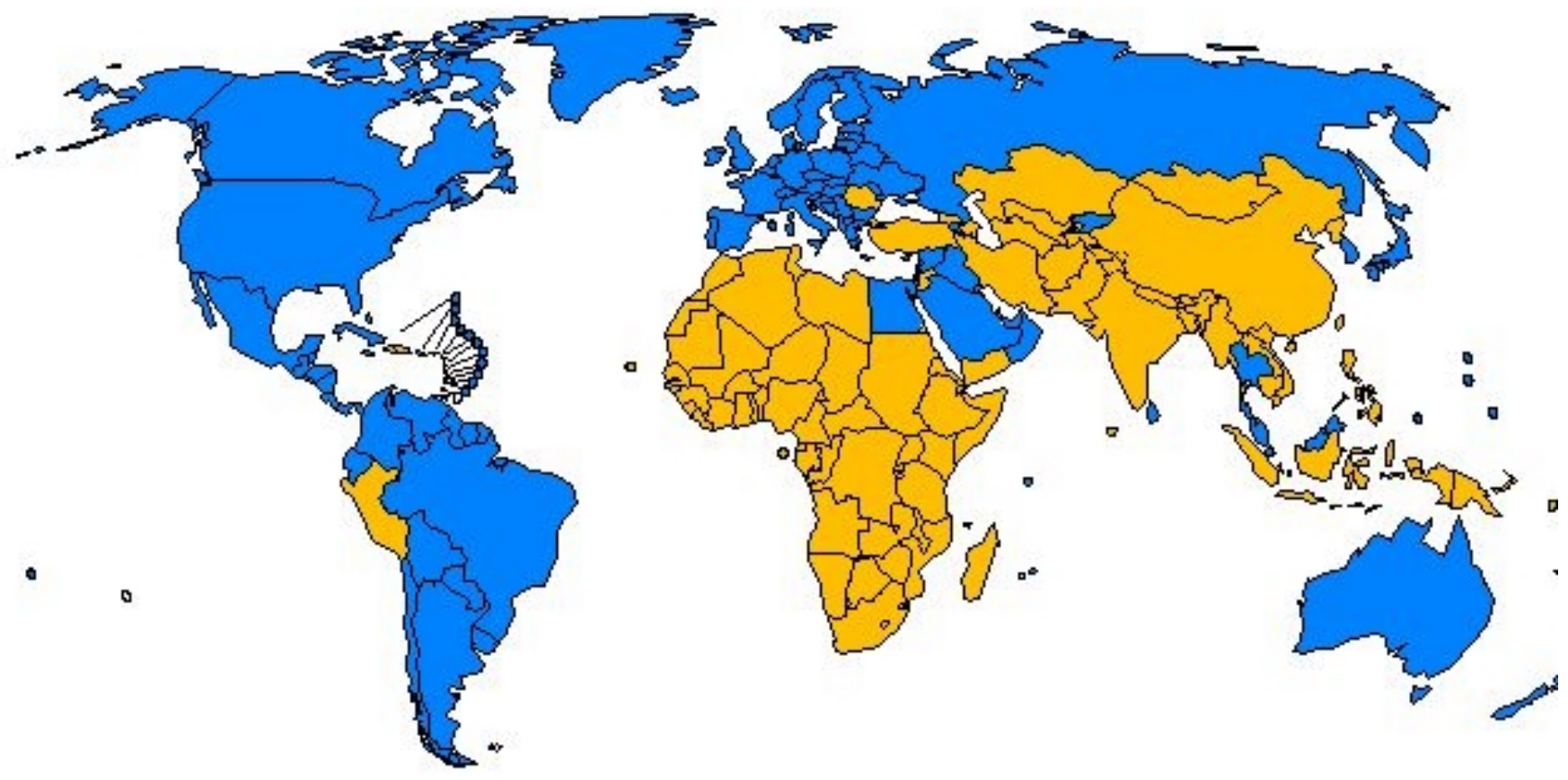

The boundaries shown on this map do not imply the expression of any opinion whatsoever on the part of the World Health Organization concerning the legal status of any country, territory, city, or area or of its authorities, or concerning the delimitation of its frontiers or boundaries. Dotted lines on the map represent approximate border lines for which there may not yet be

Yes (124 countries/territories, 58\%)

No (90 countries/territories, $42 \%$ )

full agreement.

Source: Reports to World Health Organization Department of Vaccines and Biologicals, as of May 2003.

FIGURE 2. Percentage of countries/territories, by World Health Organization region and globally, with rubella vaccine in the national immunization system, 1996 versus 2002

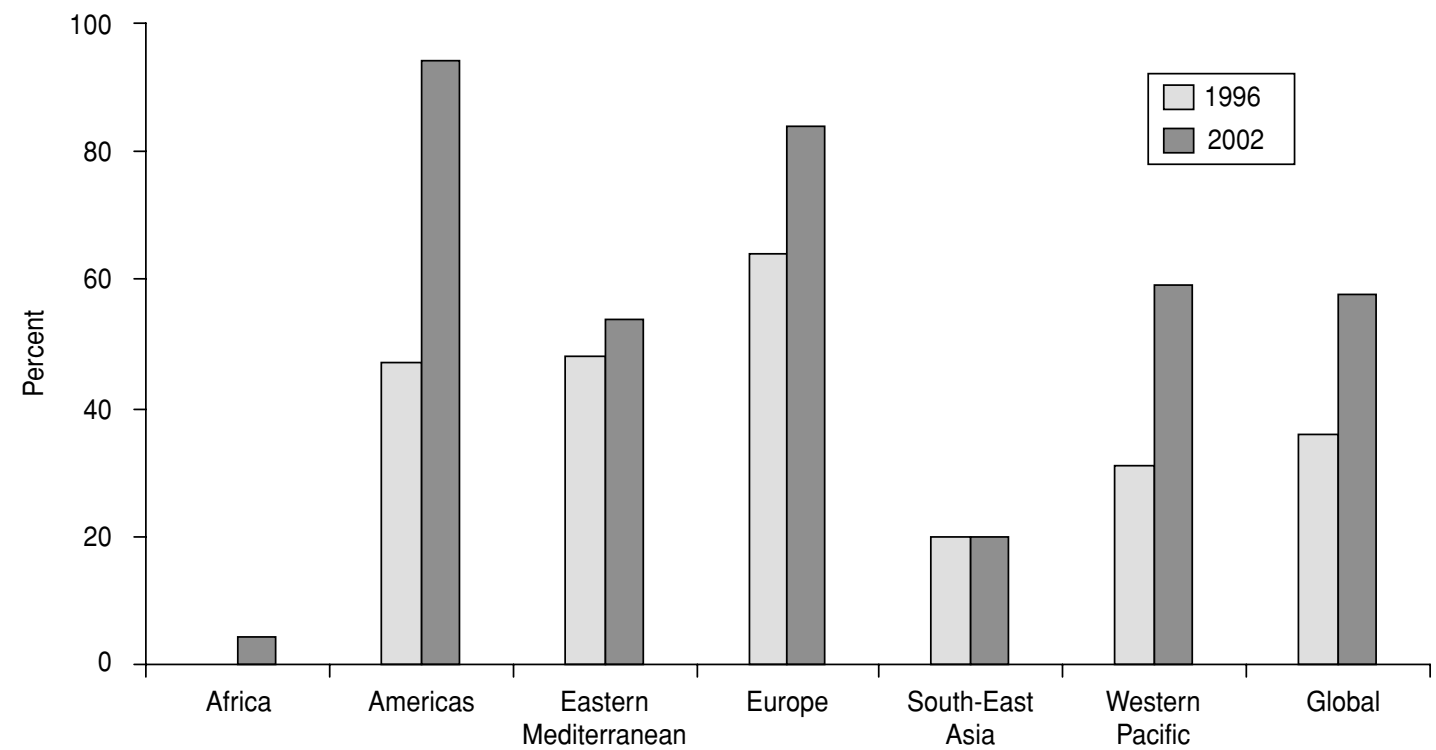

Source: Reports to World Health Organization Department of Vaccines and Biologicals, as of May 2003. 
TABLE 2. Countries with high measles vaccine coverage in children but not yet using rubella vaccine as of December 2002, by World Health Organization region, gross national product (GNP) per capita, and rubella surveillance data for 1999-2001

\begin{tabular}{|c|c|c|c|c|c|c|}
\hline \multirow[b]{2}{*}{ WHO Region } & \multirow[b]{2}{*}{ Country } & \multirow{2}{*}{$\begin{array}{c}\text { Measles vaccine } \\
\text { coverage, 1996-2001 } \\
(\%)\end{array}$} & \multirow{2}{*}{$\begin{array}{l}\text { GNP per capita } \\
\text { (US\$) }\end{array}$} & \multicolumn{3}{|c|}{ No. of rubella cases } \\
\hline & & & & 1999 & 2000 & 2001 \\
\hline Africa & Gambia & $85-92$ & 340 & NA & NA & NA \\
\hline Africa & Malawi & $81-90$ & 170 & NA & NA & 19 \\
\hline Americas & Peru & $91-97$ & 2080 & 88 & NA & 1126 \\
\hline Eastern Mediterranean & Iran & $95-99$ & 1680 & NA & 1154 & NA \\
\hline Eastern Mediterranean & Morocco & $90-96$ & 1180 & NA & NA & NA \\
\hline Eastern Mediterranean & Tunisia & $85-94$ & 2100 & NA & NA & 1012 \\
\hline Europe & Azerbaijan & $97-99$ & 600 & 504 & 219 & 441 \\
\hline Europe & Georgia & $90-99$ & NA & 799 & 428 & 293 \\
\hline Europe & Kazakhstan & $95-99$ & 1260 & 7645 & 14989 & 29271 \\
\hline Europe & Romania & $97-98$ & 1670 & 7076 & 5125 & 5076 \\
\hline Western Pacific & Samoa & $91-99$ & 1450 & NA & NA & 0 \\
\hline Western Pacific & Tuvalu & $94-99$ & NA & 0 & 0 & 0 \\
\hline Western Pacific & Viet Nam & $96-97$ & 390 & NA & NA & NA \\
\hline
\end{tabular}

Source: World Health Organization (51).

${ }^{a} \mathrm{NA}=$ Not available.

measles vaccine coverage for 5 or more years at $80 \%$ or higher (Table 2 ). These countries might consider introducing childhood rubella immunization but only if resources will permit sustained vaccination over the long term. This could be a problem since nearly half of these countries have a gross national product that is below US\$ 1000 per capita. Based on data reported to $\mathrm{WHO}$ by July 2002, 69 countries have not achieved sustained measles vaccine coverage greater than $80 \%$ in children for at least 5 years (51). For most of these countries there are other priorities related to vaccine-preventable diseases. Measles remains a major cause of child mortality. There were an estimated 745000 measles-related deaths in 2001 , with $88 \%$ of these occurring in Africa and Southeast Asia (52). Neonatal tetanus is another serious cause of child mortality, resulting in an estimated 200000 infant deaths in 2000 (53). More than 50 developing countries-most of them in either Africa or Southeast Asia-have not yet eliminated neonatal tetanus in all districts.
Increasing use by private health care providers of MMR vaccine for children in countries where rubella vaccine has not been introduced nationally by the public health care system is a concern. A recent mathematical modeling study indicates that in the short term and the long term, private-provider MMR vaccination of children alone is likely to lead to an increased incidence of CRS (54). Thus countries that do not have a national rubella vaccination program operated by the public health care system but where MMR vaccine is being used by private providers need to monitor the situation through coverage surveys and/or serosurveys to assess rubella susceptibility among women of childbearing age (35). Countries in this situation may need to consider introducing rubella vaccine for women of childbearing age.

For countries already using rubella vaccine, surveillance of rubella and CRS should be strengthened. The data in this article indicate that surveillance for rubella is improving gradually, while CRS surveillance remains gen- erally weak. Countries using rubella vaccine also need to monitor coverage of all target groups annually. It is also important to monitor the history of rubella vaccine use to know which cohorts of children and adults were vaccinated each year and how this is reflected in the national susceptibility profile for rubella, especially among women of childbearing age.

The global burden of CRS remains high, with more than 100000 infants affected each year. By the end of 2002, 124 countries/territories had introduced rubella vaccine on a national basis. A safe and effective rubella vaccine is available, and there are proven strategies for its delivery. The introduction of rubella vaccine is cost-effective and cost-beneficial, but it requires ongoing strengthening of routine immunization services and surveillance systems.

Acknowledgements. The authors thank V. Dietz, F.X. Hanon, and C. Pacis for help in updating surveillance reports. 


\section{REFERENCES}

1. Orenstein WA, Bart KJ, Hinman AR, Preblud SR, Greaves WL, Doster SW, et al. The opportunity and obligation to eliminate rubella from the United States. JAMA 1984;251:19881994.

2. Henderson RH, Keja J, Hayden G, Galazka A, Clements C, Chan C. Immunizing the children of the world: progress and prospects. Bull World Health Organ 1988;66(5):535-543.

3. Cutts FT, Robertson SE, Diaz-Ortega JL, Samuel R. Control of rubella and congenital rubella syndrome (CRS) in developing countries, part 1: burden of disease from CRS. Bull World Health Organ 1997;75:55-68.

4. Lanzieri TM, Segatto C, Siqueira MM, De Oliveria Santos EC, Jin L, Prevots R. Burden of congenital rubella syndrome after a community-wide rubella outbreak, Rio Branco, Acre, Brazil, 2000 to 2001. Pediatr Infect Dis J 2003; 22:323-329.

5. Lawn JE, Reef S, Baffoe-Bonnie B, Adadevoh S, Caul WO, Griffin GE. Unseen blindness, unheard deafness, and unrecorded death and disability: congenital rubella in Kumasi, Ghana. Amer J Pub Health 2000;90(10):1555-1561.

6. Swartz TA, Praiss I, Isacson M, Nishmi M, Ben-Porath E, Hornstein L. Early results of an extensive rubella epidemic. Int J Epidemiol 1975;4(4):331-335.

7. Baxter DN. Control of the congenital rubella syndrome in Jamaica. West Indian Med J 1986;35:50-54

8. Wynter SH, O'Gilvie CR, Khan C, Brown MG, Lindo JF, King SD. Rubella susceptibility among Jamaican women, 1996. West Indian Med J 1999;48(3):123-125.

9. Chua KB, Lam SK, Hooi PS, Chua BH, Lim CT. Retrospective review of serologic rubella activity in University Hospital Kuala Lumpur. Med J Malaysia 2000;55(3):299-303.

10. Juma AH. Infantile rubella cataract in Oman. Medical Newsletter (Oman) 1988;6(1):27-28.

11. World Health Organization, Expanded Programme on Immunization. Rubella outbreak, Oman. Wkly Epidemiol Rec 1994;69(45): 333-336.

12. Varela H, Owens C, Vásquez C, Chepote A. Rubéola congénita: estudio clínico de 50 casos. Bol Soc Panamena Pediatr 1967;1:3-11.

13. Saad de Owens C, Tristan de Espino R. Rubella in Panama: still a problem. Pediatr Infect Dis J 1989;8:110-115.

14. Sermerikov VV, Lavrentyeva IN, Popov VF, Fletcher MA, Kolotov ME. Rubella in the Russian Federation: epidemiological features and control measures to prevent the congenital rubella syndrome. Epidemiol Infect 2000; 125:359-366.

15. Tan KL, Wong TTT, Chan MCK, Chun FY, Lam SK. Congenital rubella in Singapore. J Singapore Paediatr Society 1970;12(2):111-125.

16. Gunasekera DP, Gunasekera PC. Rubella immunisation-learning from developed countries. Lancet 1996;347:1694-1695.

17. Ali Z, Hull B, Lewis M. Neonatal manifestations of congenital rubella following an outbreak in Trinidad. J Trop Pediatr 1986;32:79-82.

18. Banatvala JE. Rubella-could do better. Lancet 1998;358:849-850.
19. Cutts FT, Vynnycky E. Modelling the incidence of congenital rubella syndrome in developing countries. Int J Epidemiol 1999;28: 1176-1184.

20. World Health Organization, Regional Office for Europe. Strategic plan for measles and congenital rubella infection in the European Region of WHO, 2002-2007. Copenhagen: WHO Regional Office for Europe; 2003.

21. Reef SE, Plotkin S, Cordero JF, Katz M, Cooper L, Schwartz B, et al. Preparing for elimination of congenital rubella syndrome (CRS): summary of a workshop on CRS elimination in the United States. Clin Infect Dis 2000;31(1):85-95.

22. Cutts FT, Best J, Siqueira MM, Engstrom K, Robertson SE. Guidelines for surveillance of congenital rubella syndrome and rubella, field test version, May 1999. Geneva: WHO; 1999. (Document WHO/V\&B/99.22).

23. World Health Organization, Department of Vaccines and Biologicals. WHO-recommended standards for surveillance of selected vaccinepreventable diseases. Geneva: WHO; 2003. (Document WHO/V\&B/03.01).

24. World Health Organization. WHO recommended strategies for the prevention and control of communicable diseases. Geneva: WHO; 2001. (Document WHO/CDS/CPE/ SMT/2001.13).

25. Castillo-Solorzano C, Carrasco P, Tambini G, Reef S, Brana M, de Quadros CA. New horizons in the control of rubella and prevention of congenital rubella syndrome in the Americas. J Infect Dis 2003;187(Suppl 1):S146-S152.

26. Blitchtein-Winicki D, Silva N, Narváez M, Gonzáles J, Gonzáles M, Del Águila R, et al. Síndrome de rubéola congénita en 6 colegios para niños con sordera y/o ceguera, en Lima, Cusco y Arequipa, Perú, 1998-2000. Anales de la Facultad de Medicina Universidad Nacional Mayor de San Marcos (Peru) 2002;63(2): 93-100.

27. Vijayalakshmi P, Kakkar G, Samprathi A, Banushree R. Ocular manifestations of congenital rubella syndrome in a developing country. Indian J Ophthalmol 2002;50(4): 307-311.

28. World Health Organization. Laboratory surveillance for wild and vaccine-derived polioviruses, January 2002-June 2003. Wkly Epidemiol Rec 2003;78(39):341-346

29. World Health Organization, Department of Vaccines and Biologicals. Report of a meeting on preventing congenital rubella syndrome: immunization strategies, surveillance needs, Geneva, 12-14 January 2000. Geneva: WHO; 2000. (Document WHO/V\&B/00.10).

30. Featherstone D, Brown D, Sanders R. Development of the global measles laboratory network. J Infect Dis 2003;187(Suppl 1):S264S269.

31. Hudson P, Morgan-Capner P. Evaluation of 15 commercial enzyme immunoassays for the detection of rubella-specific IgM. Clin Diagn Virol 1996;5:21-26.

32. Frey TK, Abernathy ES, Bosma TJ, Starkey WG, Corbett KM, Best JM, et al. Molecular analysis of rubella virus epidemiology across three continents, North America, Europe, and Asia, 1961-1997. J Infect Dis 1998;178(3): 642-650.

33. Donadio FF, Siqueira MM, Vyse A, Jin L, Oliveira SA. The genomic analysis of rubella virus detected from outbreak and sporadic cases in Rio de Janeiro State, Brazil. J Clin Virol 2003;27:205-209.

34. World Health Organization. Preventing congenital rubella syndrome. Wkly Epidemiol Rec 2000;75(36):290-295.

35. World Health Organization. Rubella vaccines: WHO position paper. Wkly Epidemiol Rec 2000;75(20);161-169.

36. Hinman AR, Irons B, Lewis M, Kandola K. Economic analyses of rubella and rubella vaccines: a global review. Bull World Health Organ 2002;80(4):264-270.

37. Irons B. Rubella eradication: the countdown begins. West Indian Med J 1998;47(3):75-76.

38. World Health Organization, Programme for the Prevention of Blindness and Deafness and International Agency for the Prevention of Blindness. Preventing blindness in children: report on a WHO/IAPB scientific meeting, Hyderabad, India, 13-17 April 1999. Geneva: WHO; 2000. (WHO/PBL/00.77).

39. World Health Organization, Expanded Programme on Immunization and the WHO Department of Child and Adolescent Health and Development. Adolescent immunization. Wkly Epidemiol Rec 2000;75(22):183-187.

40. World Health Organization, Department of Reproductive Health and Research. Postpartum care of the mother and newborn: a practical guide. Geneva: World Health Organization; 1998. (Document WHO/RHT/MSM/ 98.3)

41. de Quadros CA, Hersh BS, Silveira C, Andrus JM. Eradication of wild poliovirus from the Americas: acute flaccid paralysis surveillance, 1988-95. J Infect Dis 1997;175(Suppl 1):S37-S42.

42. de Quadros CA, Olive JM, Hersh BS, Strassburg MA, Henderson DA, Brandling-Bennett $\mathrm{D}$, et al. Measles elimination in the Americas: evolving strategies. JAMA 1996;275:224-229.

43. Hersh BS, Tambini G, Nogueira AC, Carrasco $\mathrm{P}$, de Quadros CA. Review of regional measles surveillance data in the Americas, 1996-99. Lancet 2000;355:1943-1948.

44. Accelerated control of rubella and prevention of congenital rubella syndrome, Brazil. Wkly Epidemiol Rec 2002;77:169-175.

45. Pan American Health Organization. Public health burden of rubella and CRS. EPI Newsl 1998;20:2-3.

46. Hinman AR, Hersh BS, de Quadros CA. Rational use of rubella vaccine for prevention of congenital rubella syndrome in the Americas. Rev Panam Salud Publica 1998;4(3):156-160.

47. Pan American Health Organization. Annual health summit of ministers ends with focus on joint health actions [press release]. Washington, D.C.: PAHO; 2003. Available from: http://www.paho.org [Internet site]. Accessed 28 September 2003

48. Spika JS, Wassilak S, Pebody R, Lipskaya G, Deshevoi S, Guris D, et al. Measles and rubella in the World Health Organization Eu- 
ropean Region: diversity creates challenges. J Infect Dis 2003;187(Suppl 1):S191-S197.

49. Gaafar T, Moshni E, Lievano F. The challenge of achieving measles elimination in the Eastern Mediterranean Region by 2010. J Infect Dis 2003;197(Suppl 1):S164-S171.

50. Robertson SE, Cutts FT, Samuel R, DiazOrtega JL. Control of rubella and congenital rubella syndrome (CRS) in developing countries, part 2: vaccination against rubella. Bull World Health Organ 1997;75:69-80.

51. World Health Organization, Department of Vaccines and Biologicals. WHO vaccine pre- ventable diseases monitoring system: 2002 global summary. Geneva: WHO; 2002. (Document WHO/V\&B/02.20).

52. World Health Organization. Progress in preventing measles deaths globally. Wkly Epidemiol Rec 2003;78(21):184-187.

53. Vandelaer J, Birmingham M, Gasse F, Kurian M, Shaw C, Garnier S. Tetanus in developing countries: an update on the Maternal and Neonatal Tetanus Elimination Initiative. Vaccine 2003;21:3442-3445.

54. Vynnycky E, Gay NJ, Cutts FT. The predicted impact of private sector MMR vaccination on the burden of congenital rubella syndrome. Vaccine 2003;21:2708-2719.

Manuscript received 27 May 2003. Revised version accepted for publication on 30 September 2003
RESUMEN

\section{La rubéola y el síndrome de rubéola congénita: resumen de la situación actual en el mundo}

Se calcula que cada año nacen en el mundo más de 100000 niños con síndrome de rubéola congénita (SRC). La Organización Mundial de la Salud (OMS) estandarizó en 1998 las definiciones de casos para la vigilancia del SRC y de la rubéola. En 2001, 123 países o territorios notificaron 836356 casos de rubéola y se espera que el número de países se incremente a medida que se desarrolla, bajo la coordinación de la OMS, una red mundial de laboratorios para la detección del sarampión y la rubéola. Se están realizando investigaciones para mejorar la vigilancia de esta última enfermedad, entre ellas algunos proyectos encaminados a echar a andar la vigilancia y a comparan métodos diagnósticos, así como estudios de epidemiología molecular para lograr entender más a fondo los patrones de circulación del virus de la rubéola en el mundo. En 1996 una encuesta efectuada por la OMS reveló que 78 (36\%) de los 214 países o territorios que habían notificado casos de la enfermedad aplicaban la vacuna contra la rubéola como parte de su régimen de vacunación estándar. Para fines de 2002 un total de 124 de esos 214 (58\%) países o territorios aplicaban la vacuna antirrubeólica cuyo uso depende del nivel de desarrollo económico: 100\% en países industrializados, $71 \%$ en países con economías en transición y $48 \%$ en países en desarrollo. Se dispone de una vacuna inocua y eficaz y se ha demostrado la eficacia de algunas estrategias de vacunación para la prevención de la rubeóla y el SRC. En un trabajo de posición de la OMS se ofrece orientación acerca de lo que entraña, desde el punto de vista programático, emprender la vacunación antirrubeólica. Se trata de una medida cuya efectividad y beneficios superan su costo, pero que exige un continuo fortalecimiento de los servicios de vacunación y sistemas de vigilancia habituales. 